Özbay, M. ve Çelik, M.E. (2013). Türkçe öğretmeni adaylarının bilgi okuryazarlık düzeylerinin incelenmesi. Ana Dili Eğitimi Dergisi, 1(4), 10-21.

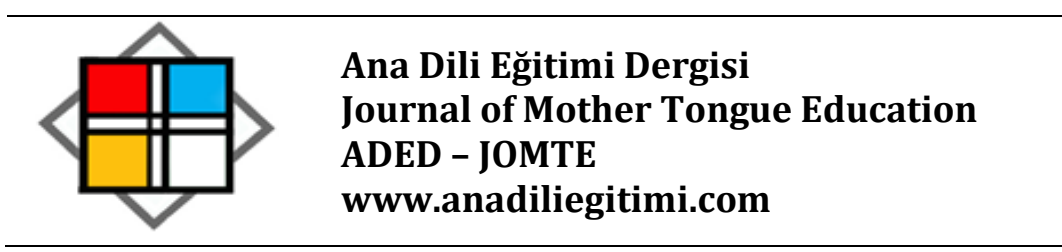

\title{
Türkçe Öğretmeni Adaylarının Bilgi Okuryazarlık Düzeylerinin İncelenmesi
}

\author{
Murat Özbay* \\ Mehmet Emre Çelik**
}

\begin{abstract}
Özet
Bu araştırmanın amacı, Türkçe öğretmeni adaylarının bilgi okuryazarlığı düzeylerini tespit etmektir. Bu bağlamda Ondokuz Mayıs, Selçuk***, Gazi, Mersin ve Dicle Üniversitelerinde öğrenimlerine devam eden toplam 666 birinci ve dördüncü sınıf öğrencisine "Bilgi okuryazarlığı ölçeği” uygulanmıştır. Çalışmada, bilgi okuryazarlığı kavramı, bilgi okuryazarlığı becerileri ve bilgi okuryazarı olmanın önemi tartışılmış; öğretmen adaylarının bilgi okuryazarlığı düzeyini belirlemek amacıyla uygulanan ölçeğin sonuçları, çeşitli değişkenler açısından irdelenmiş ve ulaşılan veriler tablolar hâlinde sunularak yorumlanmıştır.
\end{abstract}

Anahtar sözcükler: Bilgi okuryazarlı̆̆ı, Türkçe öğretmeni adayı, öğretmen yetiştirme.

\section{Review of Information Literacy Levels of Turkish Candidate Teachers}

\section{Abstract}

The aim of this research is to ascertain information literacy levels of turkish candidate teachers. In this context, "information literacy scale" is applied to students, total of 666 who are first and forth grade at Ondokuz Mayıs, Selçuk, Gazi, Mersin and Dicle universities. In this study, information literacy term, skills and importance of being information literate are argued; result of the scale on the purpose of determining candidate teachers' level of information literacy are probed in terms of several factors and commented by charts.

Key words: information literacy, Turkish candidate teachers, raising teacher

\section{Giriş}

Okuryazarlık tanımı yıllar içerisinde, farklı ihtiyaçların da oluşmasıyla değişiklik göstermiştir. Okuryazarlığın ilk tanımlarına bakıldığında 'adını okumasını ve yazmasını bilen, imza atabilen' şeklinde olduğu görülür (Güneş, 1997: 499). Unesco tarafından 1951'de düzenlenen bir toplantıda ise okuryazar, "günlük yaşamı ile ilgili basit ve kısa bir cümleyi anlayarak okuyup yazabilen kişidir" biçiminde tanımlanmıştır. 1962'ye gelindiğinde okuryazar tanımı güncellenmiş, çağın ihtiyacına cevap vereceği düşünülen bir tarife bürünmüştür: "Okuryazar, kendinin ve içinde yaşadığı toplumun gelişmesine katkıda bulunabilecek derecede okuma-yazma ve hesap yapma becerilerine sahip, grup

\footnotetext{
* Prof. Dr., Gazi Üniversitesi, Gazi Eğitim Fakültesi, Türkçe Eğitimi Bölümü, Ankara. e-posta: mozbay@gazi.edu.tr

** Arş. Gör., Ondokuz Mayıs Üniversitesi, Eğitim Fakültesi, Türkçe Eğitimi Bölümü, Samsun. e-posta: mehmetemre.celik@omu.edu.tr

*** Selçuk Üniversitesi Meram Eğitim Fakültesi'nin adı Bakanlar Kurulu kararı ile 27.12.2011 tarihinde Konya Necmettin Erbakan Üniversitesi Ahmet Keleşoğlu Eğitim Fakültesi olarak değiştirilmiştir.
} 
ve topluluk içindeki görevlerini etkin bir şekilde yerine getirebilmesi için gerekli bilgi ve becerileri kazanmış kişidir." 1965'te Tahran'da toplanan Dünya Eğitim Bakanları Kongresi'nde 'fonksiyonel okuryazarlık' kavramı ortaya atılmış ve ilerleyen yıllarda da bu kavram çok tartışılmıştır. 1975'te Persepolis'te Uluslararası Okuma Yazma Sempozyumu'nda 'okuma-yazma öğretiminin bireyin gelişmesini ve hürriyetini sağlayacak şekilde düzenlenmesi gerektiği' vurgulanmıştır. Görüldüğü gibi okuryazar kavramı, yıllar içinde değişikliğe uğramış, ve bu kavram, farklı açılardan ele alınmıştır (Güneş, 1997).

20. yüzyılın ikinci yarısından itibaren insanoğlunun hayatında daha fazla yer tutmaya başlayan elektronik teknolojik ürünler, geleneksel okuryazar tanımının yanında ihtiyaca yönelik farklı alanlarda da 'okuryazarlık' türlerinin ortaya çıkmasına neden olmuştur. Bu türlerin başlıcaları arasında; -bilgi okuryazarlığı, bilgisayar okuryazarlığı, görsel okuryazarlık, medya okuryazarlığı vb.- bulunmaktadır. Bu çalışmanın konusu bilgi okuryazarlığı olduğu için diğer türler üzerinde durulmamıştır.

Bilgi okuryazarlığı bilgiye ne zaman ve neden ihtiyaç duyulduğunu, doğru bilginin nerede bulunup nasıl saklanabileceğini, nasıl değerlendirileceğini ve etik bir biçimde nasıl paylaşılacağını bilmektir (CILIP, 2004). Bu yüzyılda veya "bilgi çağı"nda birey, pek çok farklı uyarıcı aracılığıyla adeta bilgi bombardımanına tutulmaktadır. Dolayısıyla bireyin doğru kaynağa yönlendirilmesi, bulduğu kaynaktan nasıl faydalanması gerektiğini bilmesi, belirli bir işlem sürecinden geçirip bunu eyleme dökmesi ve ulaştığı bilgiyi kurallar dâhilinde diğer bireylerle paylaşması son derece önem kazanmıştır.

Türkiye İstatistik Kurumu'nun (TÜiK) 2012 yılına ilişkin yeni yayınlanan raporu incelendiğinde; yayınlanan materyallerin oranının bir önceki yıla göre yüzde 3 arttığı görülür. 2012'de 39 bin 367 yeni kitap basımı yapılmış, 311 de web tabanlı elektronik kitap oluşturulmuştur. Bir önceki yıla göre en yüksek artış, yüzde 152,4 ile web tabanlı elektronik kitaplarda gerçekleşmiştir. Sayıları her geçen gün artan bilgi kaynaklarına bilinçli yönelim, eleştirel bakış açısı, yeniden ulaşabilme, bilgileri değerlendirme ve etik kurallara uyarak paylaşma yeteneklerine sahip olmak, bireylerin 'bilgi okuryazarı' olmalarıyla doğrudan ilişki içindedir. Bu işlevi dikkate alındığında bilgi okuryazarlığı kavramı 21. yüzyılda büyük önem arz etmektedir (Kurudayığlu ve Tüzel, 2010).

Bireyler, ihtiyacı olan bilgileri kendi yaşantılarından ya da başkalarının deneyimleri ve gözlemlerinden elde edebildikleri gibi basılı (kitap, gazete, dergi vb.) ya da elektronik (bilgisayar, tv, radyo vb.) ortamlardan da bilgiye ulaşabilmektedirler. Bir bilgiye ulaşmak için zihinde çeşitli işlem süreçleri başlatan birey, bu faaliyeti sırasında hedeflediğinden farklı bilgilerle de karşılaşabilmektedir. Bu durumda bireyin kendisine yarayacak olan bilgiye ulaşması için bireyin birtakım zihinsel faaliyetler yapması ve topladığı bilgileri zihin süzgecinden geçirmesi gerekmektedir. Bunun için de bireyin "bilgi 
okuryazarlığı" becerilerine sahip olması ve bu alanla ilgili eğitim alması günümüz şartlarında yadsınamaz bir gerçektir.

Bilgi okuryazarlığı gelişen bilgisayar teknolojileri ile birlikte bilgi teknolojisi olarak da ifade edilmektedir. Bilgi teknolojilerinden faydalanabilme becerileri bireylere kişisel amaçlarına ulaşabilmede, yazılım uygulamalarından, veri tabanlarından ve diğer teknolojik araçlardan faydalanabilme olanakları sağlamaktadır. Dolayısıyla bilgi okuryazarı bireylerden de bazı teknoloji kullanabilme becerilerine sahip olmaları beklenir. Bunlar; bilgisayar okuryazarlığı ve teknoloji okuryazarlığıdır. Günümüzde teknolojik araçlar aracılığıyla daha fazla bilginin daha geniş okur kitlelerine ulaştığı görülür. Kütüphane veya belge sağlama hizmetlerinin elektronik ortamlara taşınması olarak da adlandırılan bu yeni ortam sanal kütüphane, siber kütüphane veya elektronik kütüphane olarak da adlandırılır. Bilgi okuryazarlığı, kütüphanelerdeki bilgi birikimini güncel teknolojiden yararlanarak akademik dünyaya ulaştırmada bir köprü görevi veya mesaj aktarım rolü üstlenmektedir (Altun, 2005: 59-60).

Teknolojinin eğitimde kullanılmasıyla ilgili çalışmalar yürüten, standartlar belirleyen Uluslararası Eğitim Teknolojileri Birliği'nin (ISTE) bir öğretmen adayının öğretmenlik sertifikasına sahip olabilmesi belirlediği koşullar şunlardır:

1- Öğrencilerin öğrenmelerini kolaylaştırmak ve yaratıcılıklarını teşvik etmek.

Öğretmenler alan bilgilerini, öğrenme-öğretme süreçlerini ve teknolojiyi kullanarak yüz yüze ve sanal ortamlarda öğrencilerin öğrenmelerini, yaratıcılıklarını ve yenilikçi özelliklerini geliştirecek etkinlikler düzenler.

2- Bilgi (dijital) çağının gereklerine uygun öğrenme yaşantıları ve değerlendirme etkinlikleri tasarlamak ve geliştirmek.

Öğretmenler, etkili öğrenmelerin gerçekleşmesi için çağdaş öğrenme araçları ve kaynaklarıyla bütünleştirilmişözgün öğrenme etkinlikleri tasarlar, geliştirir ve değerlendirirler.

3- Bilgi (dijital) çağında çalışma ve öğrenme konusunda model olmak.

Öğretmenler, yenilikçi bir meslek adamı olarak bilgi toplumunun gereklerine uygun bir şekilde çalışır, buna uygun bilgi ve beceriler sergiler.

4- $\quad$ Bireyleri, bilgi (dijital) toplumu üyesi bir bireyin taşıması gereken sorumluluklarla ilgili olarak teşvik etmek ve onlara model olmak.

Sürekli gelişen ve değişen bilgi toplumunda yerel ve evrensel toplumlar sorunlar ve sorumluluklar konusunda bilgi sahibi olan öğretmenler meslek yaşamlarında etik ve yasal kurallara uymaya özen gösterirler.

5- Mesleki gelişim ve liderlik etkinliklerine katılmak. 
Öğretmenler, sürekli bir şekilde mesleki olarak kendilerini geliştirir, yaşam boyu öğrenme konusunda model olur, çalıştıkları okullarda elektronik (dijital) araç ve kaynakları etkili bir şekilde kullanarak liderlik davranışları sergilerler (ISTE'den aktaran Seferoğlu, 2009: 206-207).

Öğretmenlerin bilgi okuryazarlığı becerilerine sahip olması aynı zamanda “özel öğretmen yeterlikleri" alanına da girmektedir. Milli Eğitim Bakanlı̆ı̆'nın talebi üzerine bir komisyon tarafından "Türkçe Öğretmeni Özel Alan Yeterlikleri” (2008) belirlenmiştir. "Öğretim sürecini planlama ve düzenleme" yeterlik alanı şu alt başlıkları kapsar: "Türkçe öğretimine uygun plan yapabilme; Türkçe öğretimine uygun öğrenme ortamları düzenleyebilme; Türkçe öğretim sürecine uygun materyal ve kaynaklar kullanabilme; Türkçe öğretiminde teknolojik kaynakları kullanabilme". Bu araştırma, Türkçe öğretmeni adaylarının bilgi okuryazarlık düzeylerini ortaya çıkarıp, eksik noktalara çözüm önerileri geliştirmenin yanı sıra, öğrencilerin bilgi okuryazarlık ölçeğindeki maddeler üzerinde eğitim alıp almama ve almak isteyip istememe durumlarını tespit etmek adına önemlidir.

\section{Yöntem}

Bu araştırma tarama modeline dayanan betimsel nitelikli bir araştırmadır. Tarama modelleri, geçmişte ya da halen var olan bir durumu var olduğu şekliyle betimlemeyi amaçlayan araştırma yaklaşımlarıdır. Araştırmaya konu olan olay, birey ya da nesne, kendi koşulları içinde ve olduğu gibi tanımlanmaya çalışıır (Karasar, 2011).

\section{Örneklem}

2011-2012 öğretim yılında Ondokuz Mayıs, Gazi, Selçuk, Mersin ve Dicle Üniversiteleri Eğitim Fakülteleri'nde öğrenimlerine devam eden Türkçe Eğitimi Bölümü öğrencileri bu çalışmanın evreni olarak kabul edilmiştir.

Araştırmanın örneklemini ise Ondokuz Mayıs, Gazi, Selçuk, Mersin ve Dicle Üniversiteleri Eğitim Fakülteleri'nde öğrenimlerine devam eden Türkçe Eğitimi Bölümü’nde öğrenimlerine devam eden birinci ve dördüncü sınıf öğrencileri oluşturmaktadır. Çalışmanın örnekleminin birinci ve dördüncü sınıf öğrencilerinden oluşmasının nedeni; öğrencilerin yükseköğrenime başladıklarındaki bilgi okuryazarı olma durumları ile yükseköğrenimi bitirdiklerindeki durumlarını karşılaştırabilmek, kendilerine verilen eğitimin fark oluşturup oluşturmadığını ortaya koyabilmektir. 
Tablo-1. Araştırmanın örneklem dağılımı

\begin{tabular}{|c|c|c|c|c|}
\hline & & $\mathrm{F}$ & $\%$ & Toplam \\
\hline \multirow[t]{2}{*}{ Sinif } & 1. $\sin ı f$ & 368 & 55,3 & \multirow{2}{*}{666} \\
\hline & 4. $\sin I f$ & 298 & 44,7 & \\
\hline \multirow{4}{*}{$\begin{array}{l}\text { Mezun olunan } \\
\text { lise türü }\end{array}$} & Genel lise & 407 & 61,1 & \multirow{4}{*}{666} \\
\hline & Anadolu Lisesi & 113 & 17 & \\
\hline & Anadolu Öğretmen Lisesi & 100 & 15 & \\
\hline & Diğer & 46 & 6,9 & \\
\hline \multirow[t]{5}{*}{ Üniversite } & Ondokuz Mayıs Üniversitesi & 149 & 22,4 & \multirow{5}{*}{666} \\
\hline & Gazi Üniversitesi & 125 & 18,8 & \\
\hline & Selçuk Üniversitesi & 141 & 21,2 & \\
\hline & Mersin Üniversitesi & 168 & 25,2 & \\
\hline & Dicle Üniversitesi & 83 & 12,5 & \\
\hline
\end{tabular}

\section{Veri Toplama Araçları}

Araştırmada öğretmen adaylarının özelliklerini belirlemek amacıyla araştırmacı tarafından geliştirilen "Kişisel Bilgi Formu" uygulanmıştır. Ayrıca öğretmen adaylarının bilgi okuryazarlık durumlarına ilişkin görüşlerini belirlemek amacıyla Aldemir (2004) tarafından geliştirilen, çalışmada güvenirlik alpha katsayısı .94 bulunan "Bilgi Okuryazarlık Ölçeği” (Ek 1) kullanılmıştır. Ölçek çok zorlanıyorum (1), zorlanıyorum (2), kararsızım (3), zorlanmıyorum (4), hiç zorlanmıyorum (5) arasında değişen $5^{\prime}$ li likert tipi olup 5 maddeden oluşmaktadır. Ölçekte yer alan seçeneklerin ortalama puan karşılıkları; 4-5 "hiç zorlanmıyorum", 3-3,99 "zorlanmıyorum", 2-2,99 "kararsızım", 1-1,99 "zorlanıyorum", 0-0,99 "çok zorlanıyorum" şeklindedir. Ölçekten alınan puan arttıkça bilgi okuryazarlık düzeyi artmaktadır.

\section{Verilerin Toplanması}

Araştırmada kullanılan bilgi formu ve bilgi okuryazarlık ölçeği öğretmen adaylarına araştırmacı tarafından uygulanmıştır. Adayların kişisel bilgilerini öğrenmek için kullanılan form ile bilgi okuryazarlık düzeylerini ölçmek için kullanılan ölçek aynı anda adaylara sunulmuştur. Verilerin toplanacağı derslerde öğretim elemanları ile görüşülerek uygun zaman saptanmış ve ölçeğin gönüllü öğrenciler tarafından cevaplanmasına özen gösterilmiştir. Uygulamada herhangi bir zaman sınırı konulmamıştır.

\section{Verilerin Analizi}

Verilerin analizinde IBM SPSS Statistics 21 programı kullanılmıştır. Çalışma verileri değerlendirilirken tanımlayıı istatistiksel yöntemlerin (ortalama, standart sapma, frekans) yanı sıra niceliksel verilerin iki grup karşılaştııılmasında $T$ testi, ikiden fazla grup arası karşılaştırmalarında 
Oneway Anova testi ve farklılığa neden olan grubun tespitinde Tukey HSD testi kullanıldı. Sonuçlar \%95'lik güven aralığında, anlamlılık $p<0,05$ düzeyinde değerlendirilmiştir.

\section{Bulgular}

Bu bölümde uygulanan anket sonucu elde edilen veriler, tablolar hâlinde verilerek yorumlanmıştır.

Tablo-2. Türkçe öğretmeni adaylarının bilgi okuryazarlık düzeylerinin genel dağılımı

Bilgi okuryazarlık ölçeği genel dağılım

\begin{tabular}{|c|c|c|}
\hline $\mathrm{N}$ & $\bar{X}$ & ss \\
\hline 666 & 3,59 &, 576 \\
\hline
\end{tabular}

Tablo 2'ye göre öğretmen adaylarının bilgi okuryazarlık ölçeğinden aldıkları genel ortalama 3,6 olarak bulunmuştur. Bu sonuç ise istatistiksel olarak değerlendirildiğinde \%95 güvenle alınan genel cevabın "zorlanmıyorum" olduğu söylenebilir. Ölçeğin standart sapması ise 0,576 olarak hesaplanmıştır. Bu ölçek için standart sapmanın düşük çıkması, öğretmen adaylarının bilgi okuryazarlığı ölçeğindeki 35 soruya verdikleri cevapların uçlarda değil de ortalama puan etrafında toplandığını göstermektedir.

Tablo-3. Türkçe öğretmeni adaylarının bilgi okuryazarlık düzeyleri ile adayların öğrenim gördükleri sınıflara ilişkin T-testi sonuçları

\begin{tabular}{|l|c|c|c|c|c|}
\hline \multicolumn{1}{|c|}{ Sinıf düzeyi } & $\mathrm{N}$ & $\bar{X}$ & ss & $\mathrm{T}$ & $\mathrm{p}$ \\
\hline 1. sınıf & 368 & 3,52 &, 591 & & \\
\cline { 1 - 5 } 4. sinıf & 298 & 3,67 &, 548 & $-3,320$ & \multirow{2}{*}{, 001} \\
\cline { 1 - 5 } Toplam & 666 & 3,59 &, 576 & & \\
\hline
\end{tabular}

Türkçe öğretmen adaylarının bilgi okuryazarlık düzeyleri ile öğrenim gördükleri sınıf düzeyleri arasında anlamlı bir ilişkinin olup olmadığına sınıf düzeyleri bağımsız olduğu için Independent Samples T-Test ile karar verilecektir. Tablo 3'te T-testi sonuçları yer almaktadır. Bu tabloya göre 4. sınıf öğrencilerinin bilgi okuryazarlık puan ortalaması 3,67, 1. sınıf öğrencilerinin puan ortalaması 3,52 olarak tespit edilmiştir. T testi sonucuna bakıldığında p olasılığı 0,001 bulunmuş ve istatistiksel olarak \% 95 güvenle bilgi okuryazarlık puan ortalamaları arasında anlamlı bir farklılı̆ın olduğu tespit edilmiştir. T test istatistiğinin sonu $-3,320$ olarak bulunmuş ve bu sonuç, 4. sınıf öğrencilerinin bilgi okuryazarlık puan ortalamasının daha yüksek olduğunu göstermektedir. 
Tablo- 4. Türkçe öğretmeni adaylarının bilgi okuryazarlık düzeyleri ile öğrenim gördükleri üniversitelere ilişkin ANOVA sonuçları

\begin{tabular}{|c|c|c|c|c|c|c|}
\hline Üniversite & $\mathrm{N}$ & $\bar{X}$ & SS & $\mathrm{F}$ & $p$ & $\begin{array}{c}\text { Anlamlı } \\
\text { fark } \\
\text { (HSD) }\end{array}$ \\
\hline Ondokuz Mayıs Üniversitesi(1) & 149 & 3,68 & ,49 & \multirow{5}{*}{4,513} & \multirow{5}{*}{,001 } & \multirow{5}{*}{$\begin{array}{l}1-4 \\
2-4\end{array}$} \\
\hline Gazi Üniversitesi(2) & 125 & 3,66 & ,54 & & & \\
\hline Selçuk Üniversitesi(3) & 141 & 3,57 & ,55 & & & \\
\hline Mersin Üniversitesi(4) & 168 & 3,44 & ,63 & & & \\
\hline Dicle Üniversitesi(5) & 83 & 3,65 & 61 & & & \\
\hline
\end{tabular}

Öğrencilerin öğrenim gördükleri üniversitelere göre bilgi okuryazarlık düzeyi puan ortalamalarına bakıldığında, Ondokuz Mayıs Üniversitesi öğrencilerinin 3,68 ile en yüksek; Mersin Üniversitesi öğrencilerinin 3,44 ile en düşük ortalamaya sahip olduğu görülür. Üniversiteler arasında bilgi okuryazarlık düzeyi puan ortalamalarının farklı olup olmadığına, ikiden fazla grubun olması nedeniyle $\mathrm{F}$ testi ile karar verilmiştir. Tablo 4 'te $\mathrm{p}$ olasılık değeri 0,001 verilmiştir ve bu sonuç, istatistiksel olarak \% 95 güvenle bilgi okuryazarlık düzeyi puan ortalamalarının üniversitelere göre farklıık gösterdiği sonucunu verir. Hangi üniversiteler arasında farklılığın olduğuna HSD testi ile karar verilmiştir. HSD sonucuna göre; Ondokuz Mayıs Üniversitesi (1),Mersin Üniversitesi (4) ve Gazi Üniversitesi (2), Mersin Üniversitesi (4) arasında bilgi okuryazarlık düzeyi puan ortalamalarının farklı olduğu tespit edilmiştir.

Tablo- 5. Türkçe öğretmeni adaylarının bilgi okuryazarlık düzeyleri ile mezun oldukları lise türüne ilişkin ANOVA sonuçları

\begin{tabular}{|c|c|c|c|c|c|c|}
\hline Lise türleri & $\mathrm{N}$ & $\bar{X}$ & ss & $\mathrm{F}$ & $\mathrm{p}$ & $\begin{array}{c}\text { Anlamlı } \\
\text { fark (HSD) }\end{array}$ \\
\hline Genel Lise(1) & 407 & 3,53 & ,57 & \multirow{4}{*}{4,178} & \multirow{4}{*}{, 006} & \multirow{4}{*}{$1-3$} \\
\hline Anadolu Lisesi(2) & 113 & 3,64 &, 55 & & & \\
\hline Anadolu Öğretmen Lisesi(3) & 100 & 3,73 &, 52 & & & \\
\hline Diğer & 46 & 3,67 & ,63 & & & \\
\hline
\end{tabular}

Tablo 5'te, öğrencilerin mezun oldukları lise türlerine göre bilgi okuryazarlık düzeyi puan ortalamalarına ilişkin ANOVA sonuçları yer almaktadır. Bu sonuca göre Anadolu Öğretmen Lisesi'nden mezun olan öğrencilerin 3,73 ile en yüksek; genel liselerin herhangi birinden mezun olan öğrencilerin 3,53 ile en düşük ortalamaya sahip olduğu görülür. Tablo 4'te $p$ olasılık değeri 0,006 verilmiştir ve bu sonuç, istatistiksel olarak \% 95 güvenle bilgi okuryazarlık düzeyi puan ortalamalarının mezun olunan lise türüne göre farklılık gösterdiği sonunu verir. Hangi liseler arasında farklıığın olduğuna HSD testi ile karar verilmiştir. HSD sonucuna göre Genel lise (1) ile Anadolu öğretmen lisesi (3) arasında bilgi okuryazarlık düzeyi puan ortalamalarının farklı olduğu tespit edilmiştir. 
Tablo- 6. Türkçe öğretmeni adaylarının bilgi okuryazarlık ölçeğindeki maddelere yönelik eğitim alma durumları ve almak isteme durumlarının dağılımı

\begin{tabular}{|c|c|c|c|c|c|c|c|c|}
\hline \multirow[t]{3}{*}{ Ölçek Maddeleri } & \multicolumn{4}{|c|}{ Daha önce eğitim aldım. } & \multicolumn{4}{|c|}{ Eğitim almak istiyorum. } \\
\hline & \multicolumn{2}{|c|}{ Evet } & \multicolumn{2}{|c|}{ Hayır } & \multicolumn{2}{|c|}{ Evet } & \multicolumn{2}{|c|}{ Hayır } \\
\hline & $\mathbf{n}$ & $\%$ & $\mathbf{n}$ & $\%$ & $\mathbf{n}$ & $\%$ & $\mathbf{n}$ & $\%$ \\
\hline $\begin{array}{l}\text { 1. Ödev araştırma konusunu kendim belirlemek } \\
\text { durumunda kaldığımda }\end{array}$ & 95 & 17 & 469 & 83 & 366 & 65 & 199 & 35 \\
\hline $\begin{array}{l}\text { 2. Ödev araştırma konusuna ilişkin bilgi } \\
\text { gereksinimimi tanımlamakta }\end{array}$ & 345 & 63 & 205 & 37 & 109 & 20 & 440 & 80 \\
\hline $\begin{array}{l}\text { 3. Ödev araştırma konusunu genişletmekte ve } \\
\text { daraltmakta }\end{array}$ & 109 & 20 & 440 & 80 & 347 & 62 & 210 & 38 \\
\hline $\begin{array}{l}\text { 4. Gereksinim duyduğum bilgiyi nasıl ve nerede } \\
\text { bulacağımı bilmekte }\end{array}$ & 131 & 24 & 418 & 76 & 321 & 58 & 233 & 42 \\
\hline $\begin{array}{l}\text { 5. Bilgi aramada konuyu en iyi ifade eden (anahtar) } \\
\text { kelimeleri belirlemekte }\end{array}$ & 138 & 25 & 408 & 75 & 307 & 56 & 240 & 44 \\
\hline $\begin{array}{l}\text { 6. Hangi tür bilgi kaynağının hangi tür bilgi } \\
\text { gereksinimi için daha uygun olduğuna karar } \\
\text { vermekte }\end{array}$ & 105 & 19 & 445 & 81 & 324 & 59 & 225 & 41 \\
\hline $\begin{array}{l}\text { 7. Farklı türlerdeki bilgi kaynaklarını (ansiklopedi, } \\
\text { dergi, rehber, yıllık vb.) kullanmakta }\end{array}$ & 142 & 26 & 408 & 74 & 263 & 48 & 287 & 52 \\
\hline 8. Web kaynaklarını kullanmakta & 155 & 28 & 396 & 72 & 317 & 58 & 230 & 42 \\
\hline $\begin{array}{l}\text { 9. Bilgiye erişimi sağlayan indexleri ve elektronik } \\
\text { veri tabanlarını seçmekte ve kullanmakta }\end{array}$ & 113 & 21 & 436 & 79 & 378 & 68 & 176 & 32 \\
\hline $\begin{array}{l}\text { 10. Web arama motorlarını (Google, Yahoo vb.) } \\
\text { kullanmakta }\end{array}$ & 168 & 31 & 379 & 69 & 243 & 44,5 & 303 & 55,5 \\
\hline $\begin{array}{l}\text { 11. Elektronik bilgi erişim sistemlerindeki } \\
\text { yönlendirici bilgileri anlamakta ve uygulamakta }\end{array}$ & 117 & 21 & 430 & 79 & 300 & 54 & 251 & 46 \\
\hline $\begin{array}{l}\text { 12. Bilgisayarla bilgi ararken tarih, dil ve tür gibi } \\
\text { sınırlamalar yapmakta }\end{array}$ & 114 & 21 & 432 & 79 & 287 & 52 & 265 & 48 \\
\hline $\begin{array}{l}\text { 13. Bilgisayarla bilgi ararken kavramlar arasındaki } \\
\text { iliş̧kileri "ve,veya, değil”" kullanarak belirlemekte }\end{array}$ & 121 & 22 & 421 & 78 & 242 & 45 & 301 & 55 \\
\hline $\begin{array}{l}\text { 14. Bilgi ararken başarısız olursam farklı arama } \\
\text { yaklaşımlarını denemekte }\end{array}$ & 119 & 22 & 430 & 78 & 277 & 50 & 274 & 50 \\
\hline 15. Kütüphane kataloğunu kullanmakta & 103 & 19 & 441 & 81 & 278 & 51 & 269 & 49 \\
\hline $\begin{array}{l}\text { 16. Katalogda kaynaklarla ilgili sunulan bilgiyi } \\
\text { anlamakta }\end{array}$ & 100 & 18 & 443 & 82 & 262 & 48 & 284 & 52 \\
\hline $\begin{array}{l}\text { 17. Üniversite dışındaki diğer kütüphaneleri } \\
\text { kullanmakta }\end{array}$ & 81 & 15 & 461 & 85 & 283 & 52 & 258 & 48 \\
\hline $\begin{array}{l}\text { 18. Elde ettiğim bilginin nitelik ve nicelik açısından } \\
\text { konuya uygunluğunu değerlendirmekte }\end{array}$ & 121 & 22 & 431 & 78 & 276 & 50 & 276 & 50 \\
\hline $\begin{array}{l}\text { 19. Elde ettiğim bilgiyi güncellik, güvenirlik, } \\
\text { doğruluk tarafsızık gibi unsurlar açısından } \\
\text { değerlendirmekte }\end{array}$ & 108 & 20 & 440 & 80 & 307 & 55 & 250 & 45 \\
\hline $\begin{array}{l}\text { 20. Web kaynaklarını güncellik, güvenirlik, } \\
\text { doğruluk tarafsızlık gibi unsurlar açısından } \\
\text { değerlendirmekte }\end{array}$ & 84 & 15 & 462 & 85 & 345 & 63 & 206 & 37 \\
\hline $\begin{array}{l}\text { 21. Elde ettiğim bilgi kaynağını okuyup temel fikrini } \\
\text { belirlemekte }\end{array}$ & 166 & 30,5 & 378 & 69,5 & 268 & 49 & 281 & 51 \\
\hline $\begin{array}{l}\text { 22. Okuduğum bilgi kaynakları arasındaki benzer } \\
\text { ve farklı noktaları belirlemekte }\end{array}$ & 153 & 28 & 388 & 72 & 256 & 47 & 289 & 53 \\
\hline 23. Elde ettiğim bilgiyi yorumlamakta & 174 & 32 & 367 & 68 & 248 & 46 & 296 & 54 \\
\hline $\begin{array}{l}\text { 24. Önceki bilgilerimle yeni elde ettiğim bilgiyi } \\
\text { ilişkilendirmekte }\end{array}$ & 170 & 31 & 374 & 69 & 260 & 48 & 286 & 52 \\
\hline $\begin{array}{l}\text { 25. Kaynaklardan elde ettiğim bilgiyi kendi } \\
\text { sözcüklerimle yeniden ifade etmekte }\end{array}$ & 153 & 28 & 388 & 72 & 282 & 52 & 259 & 48 \\
\hline
\end{tabular}




\begin{tabular}{|c|c|c|c|c|c|c|c|c|}
\hline $\begin{array}{l}\text { 26. Ödev/araştırma yaparken çok sayıda kaynağı } \\
\text { bir arada kullanmakta }\end{array}$ & 150 & 28 & 393 & 72 & 290 & 53 & 256 & 47 \\
\hline $\begin{array}{l}\text { 27. Ödevin bölümlerini (kapak, içindekiler, giriş, } \\
\text { kaynakça, ekler vb.) düzenlemekte }\end{array}$ & 185 & 34 & 359 & 66 & 283 & 52 & 265 & 48 \\
\hline $\begin{array}{l}\text { 28. Ödev içinde hangi bilginin nereden alındığını } \\
\text { göstermekte (gönderme/atıf, alıntı gibi metin } \\
\text { içinde kaynak belirtme) }\end{array}$ & 182 & 33,5 & 362 & 66,5 & 283 & 52 & 265 & 48 \\
\hline $\begin{array}{l}\text { 29. Ödev/araştırmada kullandığım farklı } \\
\text { kaynakların (kitap, dergi, web sayfası gibi) listesini } \\
\text { kaynakça bilgileri hazırlamakta }\end{array}$ & 192 & 35 & 352 & 65 & 275 & 50 & 276 & 50 \\
\hline $\begin{array}{l}\text { 30. Ödev araştırma sonuçlarını sözlü olarak } \\
\text { sunmakta }\end{array}$ & 207 & 38 & 337 & 62 & 320 & 58 & 232 & 42 \\
\hline $\begin{array}{l}\text { 31. Araştırma sonuçlarımı yazılı olarak (ödev, } \\
\text { rapor, makale vb.) sunmakta }\end{array}$ & 203 & 37 & 343 & 63 & 298 & 54 & 250 & 46 \\
\hline $\begin{array}{l}\text { 32. Bilginin sunumunda sayfa sayfa sayısı, zaman } \\
\text { sınırı gibi sınırlamalara uymakta }\end{array}$ & 189 & 35 & 356 & 65 & 295 & 53 & 258 & 47 \\
\hline $\begin{array}{l}\text { 33. Bilginin iletiminde/sunumunda uygun } \\
\text { teknolojiyi kullanmakta }\end{array}$ & 199 & 36 & 350 & 64 & 335 & 60,5 & 219 & 39,5 \\
\hline $\begin{array}{l}\text { 34. Yaptığım ödevleri/araştırmaları eleştirmekte } \\
\text { (güçlü ve zayıf yönlerini tanımakta) }\end{array}$ & 141 & 26 & 403 & 74 & 310 & 56,5 & 239 & 43,5 \\
\hline $\begin{array}{l}\text { 35. Bilgi ile faaliyetlerimden ileriye yönelik dersler } \\
\text { çıkartmakta }\end{array}$ & 146 & 27 & 399 & 73 & 287 & 52 & 261 & 48 \\
\hline
\end{tabular}

Tablo 6'da Türkçe öğretmen adaylarının bilgi okuryazarlığı ölçeği maddeleri üzerinde eğitim alma ve almak isteme durumlarının dağııımı yer almaktadır. Bu dağıııma göre "Üniversite dışındaki diğer kütüphaneleri kullanmakta" ile "Web kaynaklarını güncellik, güvenirlik, doğruluk tarafsızlık gibi unsurlar açısından değerlendirmekte" maddeleri üzerinde eğitim almadığını belirten öğrencilerin oranı \%85 (462 kişi); “Ödev araştırma konusunu kendim belirlemek durumunda kaldığımda” maddesi üzerinde eğitim almak istediğini belirten öğrencilerin oranı \%65 (366 kişi); “Bilgiye erişimi sağlayan indexleri ve elektronik veri tabanlarını seçmekte ve kullanmakta" maddesi üzerinde eğitim almak istediğini belirten öğrencilerin oranı ise \%63 (345 kişi)'tür.

\section{Tartışma}

Araştırma sonucunda, öğretmen adaylarının bilgi okuryazarlık düzeylerinin "zorlanmıyorum" seçeneğinde yani orta düzeye yığıldığı görülmüştür. Korkut ve Akkoyunlu'nun (2008) çalışmasında, yabancı dil öğretmeni adaylarının bilgi okuryazarlık öz yeterlikleri puan ortalaması 3,75 (5 üzerinden) çıkmış; Başaran'nın (2005) sınıf öğretmeni adayları üzerinde yaptığı çalışmada yine adayların bilgi okuryazarlık düzeyleri "oldukça iyi" bulunmuştur. Kaya ve Durmuş'un (2008) fen bilgisi, sınıf, sosyal bilgiler ve Türkçe öğretmenliği bölümlerinde öğrenimlerine devam eden öğrenciler üzerinde yaptıkları ve örneklemi hayli geniş tuttukları çalışmada, Türkçe öğretmeni adaylarının bilgi okuryazarlık puan ortalamaları 3,89 (5 üzerinden) olarak tespit edilmiştir. Bu araştırmanın sonucu ile yukarıda verileri paylaşılan diğer çalışmaların sonuçları arasında bir paralellik olduğu görülmektedir. 
Öğretmen adaylarının bilgi okuryazarlık düzeylerinin sınıflara göre dağılımı incelendiğinde (Tablo-3) birinci sınıfa başladıklarındaki bilgi okuryazarlık düzeyleri ile dördüncü sınıfa ulaştıklarındaki düzey arasında farklıık bulunmaktadır. Öğrencilerin almış oldukları eğitim, bu farklılığın nedenidir. Mezun olunan lise türüne göre adayların bilgi okuryazarlık düzeylerine bakıldığında (Tablo-5); Anadolu Öğretmen Lisesi mezunlarının puan ortalamalarının 3,73 olduğu görülür ki bu puan genel ortalamanın da üzerindedir. Anadolu Öğretmen Lisesi öğrencilerinin aldıkları eğitimin ve okulun sahip olduğu fiziksel imkanların gözler önüne serilmesi açısından bu sonuç önemlidir.

Öğretmen adaylarına bilgi okuryazarlık ölçeği maddeleri üzerinde eğitim alıp almama ve almak isteyip istememe durumlarının incelendiği Tablo 6'da adaylar, "Bilgiye erişimi sağlayan indexleri ve elektronik veri tabanlarını seçmekte ve kullanmakta" maddesi üzerinde büyük bir çoğunlukla eğitim almak istediklerini belirtmişlerdir. İnternetin yaygınlaşması ile bilgiye erişim, bilginin sunumu ve paylaşımı daha da kolaylaşmıştır. Bu yüzden öğretmen adaylarının iyi birer bilgi okuryazarı olabilmeleri için aynı zamanda iyi birer bilgisayar kullanıcısı ve internet okuryazarı olmaları gerekir. Öğretmen adaylarının bilgi okuryazarlığına katkı sunmaları açısından; öğretim elemanlarının yürüttükleri derslerde bilgi okuryazarlığı ölçeğindeki maddelere değinmeleri ve öğrencilerine bu kazanımları alışkanlık haline dönüştürmelerinde rehber rol üstlenmeleri önemlidir.

\section{Kaynakça}

Aldemir, A. (2004). Öğretmen adaylarının bilgi okuryazarlık düzeyleri: Sakarya Üniversitesi örneği. Ankara: Hacettepe üniversitesi, Yayımlanmamış doktora tezi.

Altun, A. (2005). Gelişen teknolojiler ve yeni okuryazarlıklar. Ankara: Anı Yayıncılık.

Başaran, M. (2005). Sınıf öğretmeni adaylarının bilgi okuryazarlıklarının değerlendirilmesi. GÜ, Gazi Eğitim Fakültesi Dergisi, C. 25, S. 3, 163-177.

CILIP, (2004). “Chartered institute of library and information professionals". Internetten 15 Haziran 2013'te http://www.cilip.org.uk/get-involved/advocacy/information-literacy/Pages/definition.aspx adresinden alınmıştır.

Erdem, M. ve Akkoyunlu, B. (2002). İlköğretim sosyal bilgiler dersi kapsamında beşinci sınıf öğrencileriyle yürütülen ekiple proje tabanlı öğrenme üzerine bir çalışma. Illköğretim-online1 (1), sf. 2-11. internet'ten 20 Mayıs 2012'de http://ilkogretim-online.org.tr/vol1say1/v01s01a.pdf adresinden alınmıştır.

Güneş, F. (1997). Okur-yazarlık kavramı ve düzeyleri . A.Ü.Eğitim Bilimleri Fakültesi Dergisi, 36, 291-301.

Karasar, N. (2012). Bilimsel araştırma yöntemi. Ankara: Nobel Yayınları.

Kaya, S. ve Durmuş, A. (2008). Öğretmen adaylarının bilgi okuryazarlı̆ı̆ ve araştırma yaparken interneti kullanma düzeyleri. II. Uluslararası Bilgisayar ve Öğretim Teknolojileri Sempozyumu Sempozyum Kitabı (ss. 778-786). Kuşadası: Türkiye. 
Korkut, E. ve Akkoyunlu, B. (2008). Yabancı dil öğretmen adaylarının bilgi ve bilgisayar okuryazarlık öz yeterlikleri. Hacettepe Üniversitesi Eğitim Fakültesi Dergisi, S. 34, 178-188.

Kurudayıoğlu, M. ve Tüzel, S. (2010). 21. yüzyıl okuryazarlık türleri, değişen metin algısı ve Türkçe eğitimi.

Türklük Bilimi Araştırmaları Dergisi, Güz,S. 28, s. 283-298.

MEB, (2008). Türkçe öğretmeni özel alan yeterlikleri. s: 46-57, Ankara: MEB Basımevi.

Seferoğlu, S. S. (2009). Yeterlikler, standartlar ve bilişim teknolojilerindeki gelişmeler ışığında öğretmenlerin sürekli mesleki eğitimi. Eğitimde Yansımalar IX: Türkiye'nin Öğretmen Yetiştirme Çıkmazı Ulusal Sempozyumu Sempozyum Kitabı (ss. 204-217) Ankara: Başkent Üniversitesi.

\section{Ek 1: Bilgi Okuryazarlığı ölçeği}

\begin{tabular}{|c|c|c|c|c|c|}
\hline Ölçek Maddeleri & ن. & 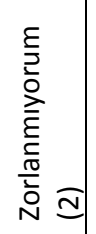 & 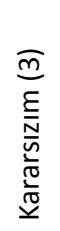 & 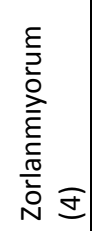 & 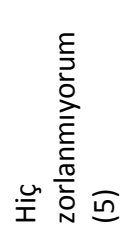 \\
\hline $\begin{array}{l}\text { 1. Ödev araştırma konusunu kendim belirlemek durumunda } \\
\text { kaldığımda }\end{array}$ & & & & & \\
\hline 2. Ödev araştırma konusuna ilişkin bilgi gereksinimimi tanımlamakta & & & & & \\
\hline 3. Ödev araştırma konusunu genişletmekte ve daraltmakta & & & & & \\
\hline 4. Gereksinim duyduğum bilgiyi nasıl ve nerede bulacağımı bilmekte & & & & & \\
\hline $\begin{array}{l}\text { 5. Bilgi aramada konuyu en iyi ifade eden (anahtar) kelimeleri } \\
\text { belirlemekte }\end{array}$ & & & & & \\
\hline $\begin{array}{l}\text { 6. Hangi tür bilgi kaynağının hangi tür bilgi gereksinimi için daha uygun } \\
\text { olduğuna karar vermekte }\end{array}$ & & & & & \\
\hline $\begin{array}{l}\text { 7. Farklı türlerdeki bilgi kaynaklarını (ansiklopedi, dergi, rehber, yıllık } \\
\text { vb.) kullanmakta }\end{array}$ & & & & & \\
\hline 8. Web kaynaklarını kullanmakta & & & & & \\
\hline $\begin{array}{l}\text { 9. Bilgiye erişimi sağlayan indexleri ve elektronik veri tabanlarını } \\
\text { seçmekte ve kullanmakta }\end{array}$ & & & & & \\
\hline 10. Web arama motorlarını (Google, Yahoo vb.) kullanmakta & & & & & \\
\hline $\begin{array}{l}\text { 11. Elektronik bilgi erişim sistemlerindeki yönlendirici bilgileri } \\
\text { anlamakta ve uygulamakta }\end{array}$ & & & & & \\
\hline 12. Bilgisayarla bilgi ararken tarih, dil ve tür gibi sınırlamalar yapmakta & & & & & \\
\hline $\begin{array}{l}\text { 13. Bilgisayarla bilgi ararken kavramlar arasındaki ilişkileri } \\
\text { "ve,veya, değil" kullanarak belirlemekte }\end{array}$ & & & & & \\
\hline $\begin{array}{l}\text { 14. Bilgi ararken başarısız olursam farklı arama yaklaşımlarını } \\
\text { denemekte }\end{array}$ & & & & & \\
\hline 15. Kütüphane kataloğunu kullanmakta & & & & & \\
\hline 16. Katalogda kaynaklarla ilgili sunulan bilgiyi anlamakta & & & & & \\
\hline 17. Üniversite dışındaki diğer kütüphaneleri kullanmakta & & & & & \\
\hline $\begin{array}{l}\text { 18. Elde ettiğim bilginin nitelik ve nicelik açısından konuya } \\
\text { uygunluğunu değerlendirmekte }\end{array}$ & & & & & \\
\hline $\begin{array}{l}\text { 19. Elde ettiğim bilgiyi güncellik, güvenirlik, doğruluk tarafsızlık gibi } \\
\text { unsurlar açısından değerlendirmekte }\end{array}$ & & & & & \\
\hline $\begin{array}{l}\text { 20. Web kaynaklarını güncellik, güvenirlik, doğruluk tarafsızlık gibi } \\
\text { unsurlar açısından değerlendirmekte }\end{array}$ & & & & & \\
\hline 21. Elde ettiğim bilgi kaynağını okuyup temel fikrini belirlemekte & & & & & \\
\hline
\end{tabular}




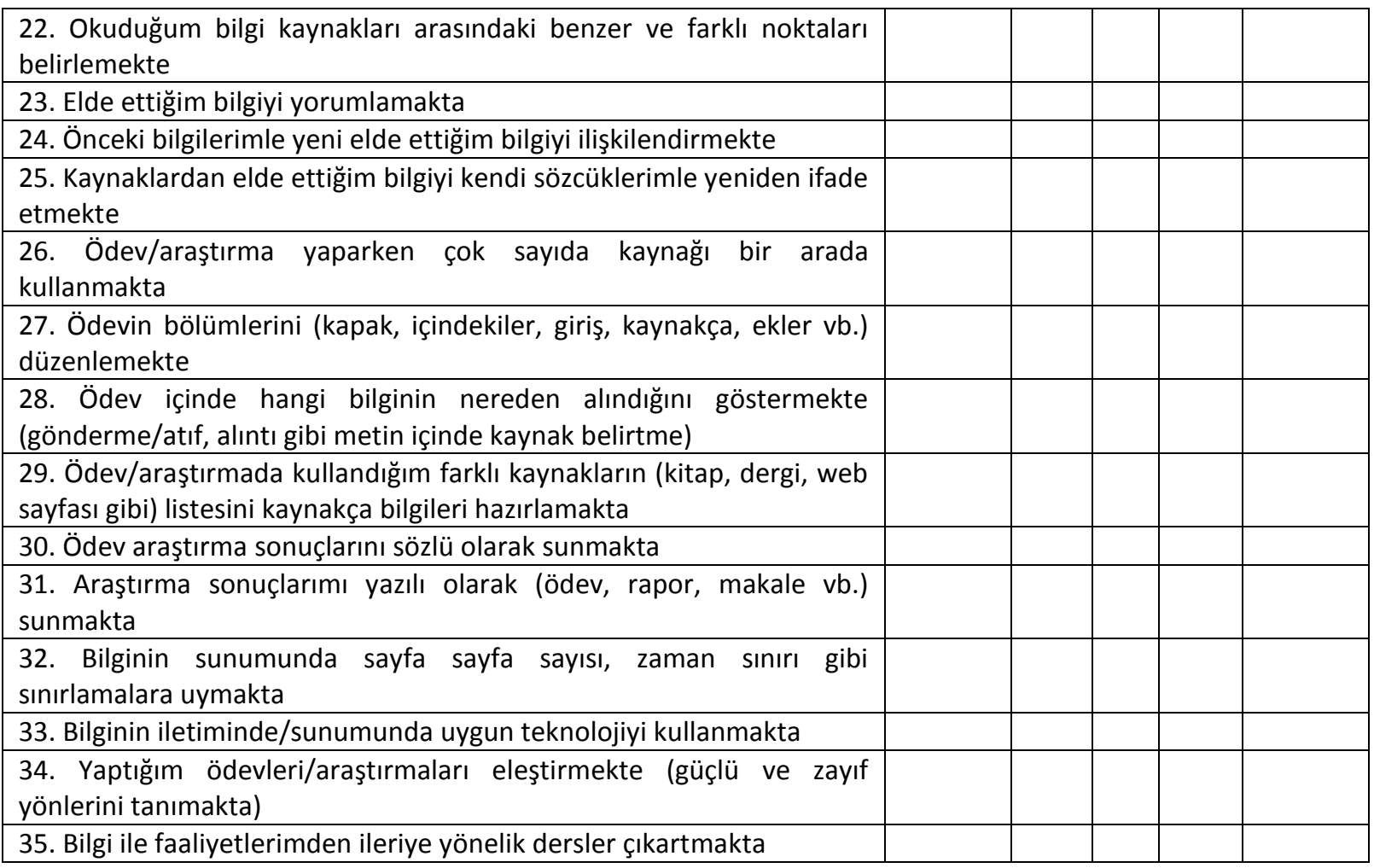

(Aldemir, 2004) 